\title{
Evaluation of the radiation dose due to the use of fly ash from thermal power plants as a building material
}

\author{
S.K. Sahu, R.C. Bhangare, P.Y. Ajmal and G.G. Pandit* \\ Environmental Monitoring and Assessment Section, Health Safety and Environment Group, Bhabha Atomic Research Centre, Trombay, \\ 400085 Mumbai, India.
}

Received 14 July 2015 - Accepted 15 February 2016

\begin{abstract}
A study was undertaken to evaluate the radiation doses arising from a dwelling built using fly ash as one of the components of the concrete in different proportions. The radioactivity contents of the fly ash samples were determined and doses to occupants were calculated assuming different scenarios. The internal dose in an office and home were in the range of 0.028 to $0.049 \mathrm{mSv}_{\text {year }}{ }^{-1}$ and 0.099 to $0.17 \mathrm{mSv}$ year ${ }^{-1}$, respectively. The external doses ranged between 0.046 and $0.21 \mathrm{mSv}_{\text {year }}{ }^{-1}$ in the office and 0.1 and $0.69 \mathrm{mSv}^{-1} \mathrm{ear}^{-1}$ in the home. The cumulative dose from the use of fly ash as a building material ranged from 0.074 to $0.26 \mathrm{mSv}_{\text {year }}{ }^{-1}$ in the office and 0.2 to $0.86 \mathrm{mSv}$ year $^{-1}$ in the home.
\end{abstract}

Keywords: dose equivalent / effective: exposure / radiation: fly ash: radiation / technological enhancement

\section{Introduction}

All building materials contain naturally occurring radionuclides, mainly from the uranium and thorium decay series. The use of such materials containing naturally occurring radionuclides for house construction may enhance the natural radiation background to which some population groups are exposed. Living in a house built with materials containing naturally occurring radionuclides in excess could be one of the causes of radiation exposure. Radionuclides in building materials of dwellings are sources of both external and internal exposure to the occupants. External exposure is caused by gamma rays from radionuclides such as ${ }^{40} \mathrm{~K},{ }^{226} \mathrm{Ra}\left({ }^{238} \mathrm{U}\right.$ decay series) and ${ }^{232} \mathrm{Th}$ decay series radionuclides, while the internal exposure is mainly caused by alpha particles due to inhalation of radioactive inert gases such as radon and its short-lived products, which emanate from the building material and are deposited on the respiratory tract tissues (UNSCEAR, 2000). Naturally occurring radon isotopes contribute more than $50 \%$ of the radiation dose received by individuals from natural radiation sources, and they are known as the second leading cause of lung cancer after tobacco smoking (UNSCEAR, 2000; WHO, 2009).

The natural isotopes of radon, ${ }^{222} \mathrm{Rn}$ and ${ }^{220} \mathrm{Rn}$, are members of the ${ }^{238} \mathrm{U}$ and ${ }^{232} \mathrm{Th}$ decay series, respectively. They emanate through the pores of grains of the concrete and then migrate from the building materials into the atmosphere, before undergoing radioactive decay. This exhalation process plays an important role in outdoor and indoor radon concentrations

^ ggp@barc.gov.in
(Hassan et al., 2010). While ${ }^{222} \mathrm{Rn}\left(T_{1 / 2}=3.82 \mathrm{~d}\right)$ can migrate a significant distance, ${ }^{220} \mathrm{Rn}\left(T_{1 / 2}=56 \mathrm{~s}\right)$ levels are extremely dependent on the distance from the source. Exposure to ${ }^{220} \mathrm{Rn}$ can be significant only in closed dwellings or near wall positions. So, basements, beds positioned close to the wall in a corner position, or sleeping facilities directly on the ground are more prone to ${ }^{220} \mathrm{Rn}$ exposure (Steinhäusler, 1996; Veiga et al., 2006). The monitoring of radiation doses arising due to the use of such materials is thus very important. Provided that the activity concentrations of the radionuclides in these materials are known, the absorbed dose and inhalation dose in air inside a room can be calculated. Mathematical models can be used to predict external and internal dose rates inside a room, provided the compartment geometry and the radionuclide concentration activities are known (Máduar and Hiromoto, 2004; de Jong and van Dijk, 2008; Krieger, 1981; Righi and Bruzzi, 2006).

For the estimation of radiological hazards to human health due to natural radioactivity in building materials, several methods have been developed in the past. For external gamma dose rate calculations, mathematical models were adapted to estimate conversion factors $\left(\mathrm{nGy} \mathrm{h} \mathrm{h}^{-1}\right.$ per $\mathrm{Bq} \mathrm{kg} \mathrm{kg}^{-1}$ ) for the most common exposure geometries and radionuclide distributions. These conversion factors are very useful to predict exposure due to natural radionuclides (UNSCEAR, 1993; WHO, 2009). Indoor exposure due to natural radionuclides in building materials can also be calculated using mathematical models that consider geometry variation according to the building design and building material (Stranden, 1979; Koblinger, 1984; Markkanen, 1995). Assessments of the radiation hazard 
to the lung and respiratory tract due to the radioactive inert gas radon, however, requires additional parameters, because the radon concentration in dwellings depends on material properties such as density, porosity and thickness, as well as on the environmental conditions, such as relative humidity, temperature, air-flow direction and frequency of air changes (UNSCEAR, 1982, 1988; Rizzo et al., 2001; Anjos et al., 2010; Da Silva et al., 2011).

Coal-fired thermal power plants all over the world produce enormously huge amounts of fly ash as a byproduct. The disposal of this huge amount of ash is a problem both from the environmental as well as economic point of view. Thus, different ways are being discovered for utilization of this fly ash for different purposes. In this regard, nowadays, due to its cementitious properties, the use of fly ash in building materials is increasing worldwide. The use of this fly ash, which contains elevated levels of natural radioactivity, could lead to radiation exposure to the public from the buildings where it is used. It is thus necessary to estimate the dose due to the use of fly ash in construction materials in order to assess the risk to occupants of such buildings. This paper presents a methodology for theoretical evaluation of indoor external gamma and internal radon doses in the air of a hypothetical room made of construction material incorporating fly ash as one of the concrete components. Doses were evaluated taking into account different variations in the construction material and the type of the dwelling. Calculations were performed for observed radioactivities of ${ }^{40} \mathrm{~K},{ }^{226} \mathrm{Ra}$ and ${ }^{232} \mathrm{Th}$ in fly ash samples from different coal-fired thermal power plants.

\section{Materials and methods}

\subsection{Sample collection and preparation}

Fly ash samples were collected from 6 different thermal power plants across India on 5 different days (once a week) over a period of one month. The samples were collected from the hoppers of the electrostatic precipitators. The efficiency of the electrostatic precipitators was as high as $99 \%$ in all the plants. The gross samples were further milled, and split carefully in accordance with ISO recommendations to obtain a representative subsample for further analysis (Bhangare et al., 2014).

The samples were dried for $24 \mathrm{~h}$ in an air-circulation oven at $110{ }^{\circ} \mathrm{C}$, powdered, homogenized, and about $100 \mathrm{~g}$ of each sample were placed in plastic containers which were sealed to make them airtight for 1 month to ascertain establishment of secular equilibrium between ${ }^{226} \mathrm{Ra}$ and ${ }^{228} \mathrm{Th}$ and their daughters and to prevent radon loss. After attainment of secular equilibrium, the samples were subjected to gamma-ray spectrometric analysis.

\subsection{Gamma spectrometric analysis}

A gamma-spectrometry system with $n$-type coaxial HPGe detector (DSG, Germany) shielded with 7.5-cm-thick lead with $50 \%$ relative efficiency and a resolution of $2.1 \mathrm{keV}$ at
1.33 MeV gamma energy of ${ }^{60} \mathrm{Co}$ was used. The gamma spectra acquired for $60000 \mathrm{~s}$ were analyzed using an 8K PC-based multichannel analyzer (PHAST, Electronics Division, BARC).

\subsection{Quality control and quality assurance}

For gamma spectrometry, energy calibration of the system was done initially with ${ }^{241} \mathrm{Am},{ }^{137} \mathrm{Cs}$ and ${ }^{60} \mathrm{Co}$ as a mixed radionuclide point source. Also, the source was counted for 2000 seconds to check energy calibration between the sample measurements. For quality assurance, the IAEA standard reference materials (a standard soil of known radioactivity, Soil6, a uranium ore sample, RGU1, and a thorium ore sample, RGTh1) were also used for checking the efficiency calibration of the system.

\subsection{Internal and external doses}

To assess the radiological hazard of fly ash and bottom ash used as building materials, the radium equivalent activity $\left(R a_{\text {eq }}\right)$ is used. $R a_{\text {eq }}$ can be calculated as

$$
R a_{\mathrm{eq}}=A_{\mathrm{Ra}}+1.43 A_{\mathrm{Th}}+0.077 A_{\mathrm{K}}
$$

where $A_{\mathrm{Ra}}, A_{\mathrm{Th}}$ and $A_{\mathrm{K}}$ are the activity concentrations of ${ }^{226} \mathrm{Ra}$, ${ }^{232} \mathrm{Th}$ and ${ }^{40} \mathrm{~K}$ in $\mathrm{Bq} \mathrm{kg}{ }^{-1}$, respectively. $R a_{\mathrm{eq}}$ is related to the external $\gamma$-dose and internal dose due to radon and its daughters. The maximum value of $R a_{\mathrm{eq}}$ in building materials must be less than $370 \mathrm{~Bq} \mathrm{~kg}^{-1}$, as recommended by UNSCEAR (1988).

In order to calculate the radon production rate of a concrete sample, the radium specific activity of all concrete constituents must be known. In this study, the radium specific activity of the concrete constituent fly ash was determined from experimental data, whereas for cement, it was taken from the literature. Each constituent's radium specific activity was multiplied by the constituent's weight percent and each term was summed to create a concrete mixture's specific activity according to ACI guidelines (ACI, 2009), as shown in the following equation:

$$
Q=X R a_{\mathrm{FA}}+Y R a_{\mathrm{C}}\left(\mathrm{Bq} \mathrm{kg}^{-1}\right)
$$

where $Q$ is the radium specific activity $\left(\mathrm{Bq} \mathrm{kg}^{-1}\right)$ of the concrete mixture, and $R a_{\mathrm{FA}}$ and $R a_{\mathrm{C}}$ are the radium specific activities of the constituents fly ash and cement, respectively. $X$ and $Y$ represent the quantity of fly ash and cement, respectively. Other constituents of the concrete were not taken into consideration in this study in order to estimate the dose from maximum fly ash use conditions. Four concrete mixtures were taken by varying the amount of fly ash, $X$, in the concrete as follows: (i) low fly ash (25 wt\% of the concrete), (ii) half fly ash (50 wt \%), (iii) high fly ash (75 wt \%) and (iv) total fly ash $(100 \%)$. The specific activity of water, which comprises $5 \mathrm{wt} \%$ of the concrete, was considered negligible for this analysis.

For estimation of the dose in a closed room, a hypothetical dwelling was considered. The dwelling was geometrically defined as a single room consisting of a set of three pairs of rectangular slabs of finite thickness. The dimensions of the hypothetical room were $4 \mathrm{~m} \times 5 \mathrm{~m} \times 2.8 \mathrm{~m}$. Doors and windows 
were not considered in the present study. The dose conversion factors in $\mathrm{nGy} \mathrm{h}^{-1}$ per $\mathrm{Bq} \mathrm{kg}{ }^{-1}$ for the radionuclides ${ }^{226} \mathrm{Ra}$, ${ }^{232} \mathrm{Th}$ and ${ }^{40} \mathrm{~K}$ were taken from (Máduar and Hiromoto, 2004) as $0.7,0.92$ and 0.072 , respectively. The external dose was estimated using a simple linear function given by

$$
D=\sum Q_{\mathrm{i}} C_{\mathrm{i}}
$$

where $D$ is the absorbed dose rate in air $\left(\mathrm{Gy} \mathrm{s}^{-1}\right), Q_{\mathrm{i}}$ is the dose conversion factor for the radionuclide of the decay series $i\left(\mathrm{~Gy} \mathrm{~s}^{-1}\right.$ per Bq kg$\left.{ }^{-1}\right)$, and $C_{\mathrm{i}}$ is the activity concentration of the radionuclide of the decay series $i\left(\mathrm{~Bq} \mathrm{~kg}^{-1}\right)$. The dose to the occupant of the room also depends upon the time spent by $\mathrm{him} / \mathrm{her}$ in the room. The external dose can thus be given by

$$
\text { External Dose }=\text { Dose Rate } \times \text { Exposure Time } .
$$

The occupants of the room are also subjected to internal exposure due to diffusion of radionuclides in the room air from the wall surfaces. The internal dose is received mainly due to radon emanation in the air from the building material. In order to calculate the radon production rate of a concrete sample, the radium specific activity of all concrete constituents must be known. Once the radium specific activity $(Q)$ is known, the radon exhalation rate is given by (ACI, 2009) as

$$
J_{\mathrm{f}}=Q \eta \rho f l_{\mathrm{o}} \tan h\left(d / l_{\mathrm{o}}\right)\left(\mathrm{Bq} \mathrm{m}^{-2} \mathrm{~s}^{-1}\right)
$$

where $J_{\mathrm{f}}$ is the radon exhalation rate from the building element $\left(\mathrm{Bq} \mathrm{m} \mathrm{m}^{-2} \mathrm{~s}^{-1}\right), \eta$ is the decay constant of radon $\left(2.1 \times 10^{-6} \mathrm{~s}^{-1}\right)$, $\rho$ is the density of the concrete (assumed to be $2500 \mathrm{~kg} \mathrm{~m}^{-3}$ ), $f$ is the radon emanation fraction or the amount of radon released from the grain to pore space relative to the total radium content in the particle, $l_{\mathrm{o}}$ is the diffusion length in the concrete and $d$ is the half-thickness of the building element. The emanation fraction and diffusion length were taken as $5 \%$ and $0.2 \mathrm{~m}$, respectively (Siotis and Wrixon, 1984). The literature shows various emanation fractions that range from 1\%-25\% (Kovler, 2012; Taylor-Lange et al., 2014). However, the value of 5\% is most cited, hence this value was used in this study. The indoor radon concentration and associated alpha exposures are thus given by

$$
C \text { ss }=J_{\mathrm{f}} A / \lambda V\left(\mathrm{~Bq} \mathrm{~m}^{-3}\right)
$$

where $C$ ss is the steady-state indoor radon concentration, $\lambda$ is the air exchange rate in $\mathrm{s}^{-1}, A$ is the concrete surface area in $\mathrm{m}^{2}$ and $V$ is the volume of the home in $\mathrm{m}^{3}$. The assumptions for this dose calculation include: (i) steady-state conditions, (ii) limited removal of radon and daughter products, due to the attachment of indoor aerosols, and (iii) limited interference with radon emission due to floor and wall coverings. These assumptions are consistent with those made by (Nazaroff and Nero, 1988). Additionally, only airborne concentrations of radon were considered; the formation and fate of daughter isotopes were disregarded in this study. The air exchange rate was taken as $1.5 \mathrm{~h}^{-1}$ (Murray and Burmaster, 1995). In addition, variations due to the concrete surface treatment, temperature, building moisture and air pressure gradients were considered negligible. The internal dose is given as

$$
\text { Internal Dose }=C \text { ss } \times \mathrm{IR} \times \mathrm{DCF} \times \mathrm{IOF}
$$

where IR $=$ Inhalation rate $\left(1.2 \mathrm{~m}^{3} \mathrm{~h}^{-1}\right), \mathrm{DCF}=$ Dose conversion factor and IOF $=$ Indoor occupancy factor (0.8). The other values used for calculations of the doses are shown in Table 1. Here, the internal dose is not considered as a lifetime committed dose; rather, it is expressed as the annual equivalent dose.

\section{Results and discussion}

\subsection{Radioactivity in fly ash}

All the fly ash samples showed detectable amounts of radionuclides in them. The gamma spectrometrically determined activity concentrations of fly ashes from different thermal power plants along with their calculated radium equivalent activities $\left(R a_{\text {eq }}\right)$ are shown in Table 2 . The fly ash from plant 2 showed the highest activity concentrations for all the radionuclides, which were 83.1-115.2, 94.3-142.6 and 172.3223.6 Bq kg-1 for ${ }^{226} \mathrm{Ra},{ }^{232} \mathrm{Th}$ and ${ }^{40} \mathrm{~K}$, respectively. The fly ash from plant 1 showed the minimum total activity. The $R a_{\text {eq }}$ values for fly ashes from all the plants varied between 93.1 and $299.9 \mathrm{~Bq} \mathrm{~kg}^{-1}$. It is noteworthy that none of the $R a_{\mathrm{eq}}$ values of the samples exceeded the prescribed limit of $370 \mathrm{~Bq} \mathrm{~kg}^{-1}$. Except for plant 2's and plant 6's ashes, the $R a_{\mathrm{eq}}$ values were below $200 \mathrm{~Bq} \mathrm{~kg}^{-1}$ in the samples from the rest of the plants.

\subsection{Dependence of the dose on the percentage of fly ash}

Normally, fly ash is not used as the single component of the concrete. It forms a part of the concrete as a replacement for other components. The percentage of fly ash could be anything between 0 and $100 \%$ of the concrete. Thus, to evaluate the doses from the use of different proportions of fly ash in the building material, four different percentages of the ash were taken into consideration. The doses were calculated for both office and home scenarios. Table 3 shows the average (average of all 6 plants) doses due to varying amounts of fly ash as a building material. It was assumed that the building materials were different combinations of fly ash and cement (i.e. \% fly ash $+\%$ cement $=100$ ) only. The activity concentration of the remaining percentage of cement in the concrete was taken as $50 \mathrm{~Bq} \mathrm{~kg}^{-1}$, as suggested by UNSCEAR (1982). It can be observed that the dose increases with the increase in the percentage of fly ash. In general practice, the maximum ratio of fly ash and cement used in concrete is 50-50\%. The external and internal doses in an office and home for a scenario utilizing $50 \%$ fly ash were 0.057 and 0.138 , and 0.056 and $0.198 \mathrm{mSv}_{\text {year }}{ }^{-1}$, respectively.

\subsection{Dose to the room occupants}

The internal and external doses to the occupants in the hypothetical room were calculated considering two scenarios, i.e. an office scenario and a home scenario. The exposure time in the office was taken to be 8 hours a day and 5 days a week, 
Table 1. The parameter values used in calculating the external dose.

\begin{tabular}{lccc}
\hline Dimensions of the room & $4 \mathrm{~m} \times 5 \mathrm{~m} \times 2.8 \mathrm{~m}$ \\
Thickness and density of the structure & $20 \mathrm{~cm}, 2350 \mathrm{~kg} \mathrm{~m}^{-3}$ (concrete) & & \\
Annual exposure time & $7000 \mathrm{hrs}$ (Home) & & \\
& $2000 \mathrm{hrs}($ Office) & & \\
Dose conversion factor & $0.7 \mathrm{~Sv} \mathrm{~Gy}^{-1}$ & & \\
Background radiation level & $50 \mathrm{nGy} \mathrm{h}^{-1}$ & & \\
Dose conversion factors (specific dose rates) & ${ }^{226} \mathrm{Ra}^{232} \mathrm{Th}$ & ${ }^{40} \mathrm{~K}$ \\
$\mathrm{nGy} \mathrm{h}^{-1}$ per Bq kg & 0.7 & 0.92 & 0.072 \\
\hline
\end{tabular}

Table 2. Activity concentrations of the radionuclides in fly ash.

\begin{tabular}{|c|c|c|c|c|}
\hline Fly ash & ${ }^{226} \mathrm{Ra}\left(\mathrm{Bq} \mathrm{kg}{ }^{-1}\right)$ & ${ }^{232} \mathrm{Th}(\mathrm{Bq} \mathrm{kg}-1)$ & ${ }^{40} \mathrm{~K}\left(\mathrm{~Bq} \mathrm{~kg}{ }^{-1}\right)$ & 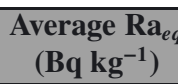 \\
\hline Plant 1 & $48.3-71.1$ & $34.3-54.2$ & $38.4-60.1$ & 93.1 \\
\hline Plant 2 & $83.1-115.2$ & $94.3-142.6$ & $172.3-223.6$ & 299.9 \\
\hline Plant 3 & $62.3-93.4$ & $33.6-51.4$ & $36.3-56.7$ & 139.8 \\
\hline Plant 4 & $73.2-107.5$ & $29.7-44.3$ & $72.1-96.3$ & 148.9 \\
\hline Plant 5 & $50.7-72.6$ & 72.4-101.5 & $61.4-82.4$ & 189.7 \\
\hline Plant 6 & $71.5-96.3$ & 98.4-138.7 & $105.4-156.7$ & 261.8 \\
\hline
\end{tabular}

Table 3. Dose with varying percentage of fly ash.

\begin{tabular}{lcccc}
\hline Assumed \%age of fly ash* & \multicolumn{2}{c}{ Internal dose (mSv/year) } & \multicolumn{2}{c}{ External dose (mSv/year) } \\
\cline { 2 - 5 } & Office & Home & Office & Home \\
\hline 25\% fly ash & 0.04 & 0.14 & 0.028 & 0.039 \\
50\% fly ash & 0.056 & 0.198 & 0.057 & 0.138 \\
75\% fly ash & 0.073 & 0.257 & 0.085 & 0.238 \\
100\% fly ash & 0.09 & 0.316 & 0.114 & 0.338 \\
\hline
\end{tabular}

* Remaining \% age is the cement.

whereas for the home the exposure time was considered to be a whole year with an occupancy factor of 0.8 . The estimated yearly internal dose to the occupants of the room due to the use of $100 \%$ fly ash (extreme conditions) as the construction material of the room is shown in Figure 1.

The internal dose in the office varied from 0.05 to $0.14 \mathrm{mSv}$ year ${ }^{-1}$, while in the home it varied between 0.19 and $0.49 \mathrm{mSv}$ year $^{-1}$ for different fly ashes. As expected, the maximum internal doses were observed for fly ash from plant 2 and plant 6.

The estimated yearly external doses due to the use of $100 \%$ fly ash from different plants as the construction material for the hypothetical room are shown in Figure 2. The external doses ranged between 0.046 and $0.21 \mathrm{mSv}$ year $^{-1}$ in the office and 0.1 and $0.69 \mathrm{mSv}$ year $^{-1}$ in the home. The maximum external doses were observed for fly ash from plant 2 and plant 6. The cumulative dose (i.e. internal + external) from the use of $100 \%$ fly ash as the building material ranged from 0.1 to $0.3 \mathrm{mSv}_{\text {year }}-1$ in the office and 0.3 to $0.9 \mathrm{mSv}$ year $^{-1}$ in the home. None of the doses exceeded the value of $1 \mathrm{mSv}$ year ${ }^{-1}$.

\subsection{Dose dependence on particle size}

To study the dependence of the dose on particle size, the fly ash from plant one was segregated into different size fractions $(2 \mu \mathrm{m}, 4 \mu \mathrm{m}, 6 \mu \mathrm{m}$ and $18 \mu \mathrm{m})$ using a magnetic sieve shaker, and these fractions were further analyzed for their ac- tivity determination (Sahu et al., 2014). The dose from different size fractions was calculated considering the use of $50 \%$ fly ash in the cement. The results are shown in Figure 3. It was observed that the dose increased with the decrease in particle size of the fly ash. It can be seen that the increase in the dose from total fly ash to the finest fraction was about $130 \%$ in the office and about $140 \%$ in the home. This is obvious, as the concentration of elements in fly ash depends largely on the size fractions of the escaping fly ash (Bhangare et al., 2011), and also radon emanation can be dependent on particle size (Sakoda et al. 2010). The decrease in particle size increases the surface area per unit mass, thus offering more surface for the radionuclides to become adsorbed. Thus, a higher activity concentration is found in finer size fractions of the fly ash.

\section{Conclusion}

The presence of naturally occurring radionuclides in fly ash can result in exposure of the people occupying buildings built with fly ash as one of the constituents of the construction material. The doses were calculated from activity concentrations of fly ash samples collected from 6 different power plants. It was observed that none of the $R a_{\text {eq }}$ values of the samples exceeded the prescribed limit of $370 \mathrm{~Bq} \mathrm{~kg}^{-1}$. The cumulative dose from the use of fly ash as a building material ranged from 0.1 to $0.3 \mathrm{mSv}$ year $^{-1}$ in the office and 0.3 to $0.9 \mathrm{mSv}$ year $^{-1}$ in the home. None of the doses exceeded the 


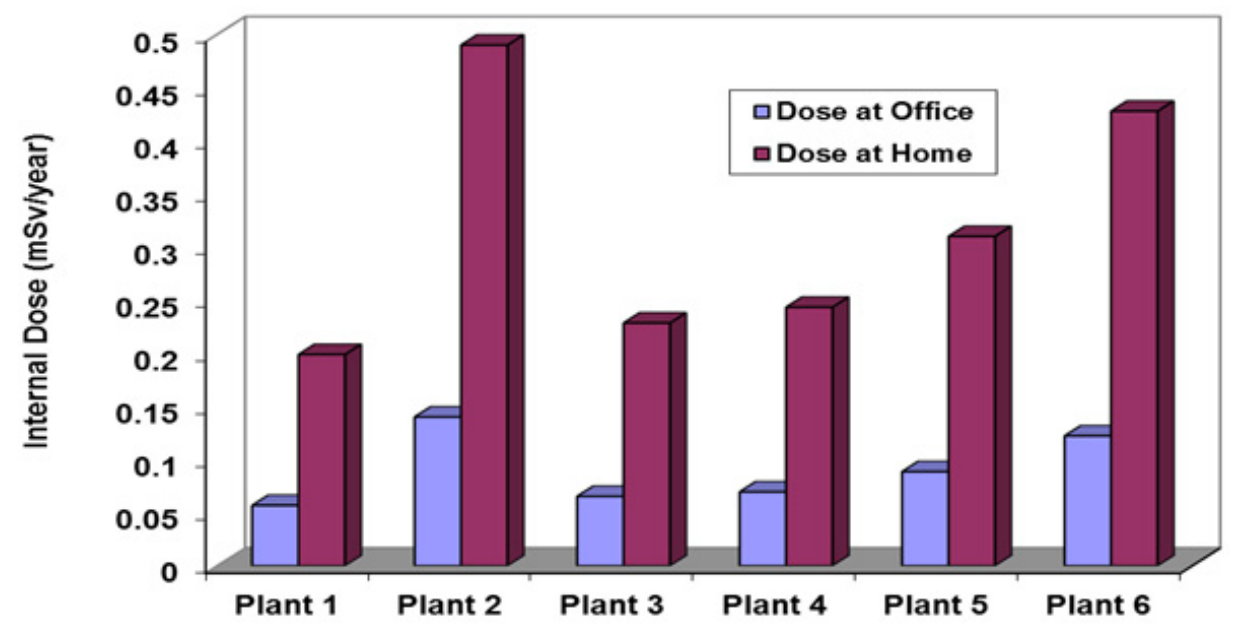

Figure 1. Yearly internal dose to the occupants due to the use of fly ash as a construction material.

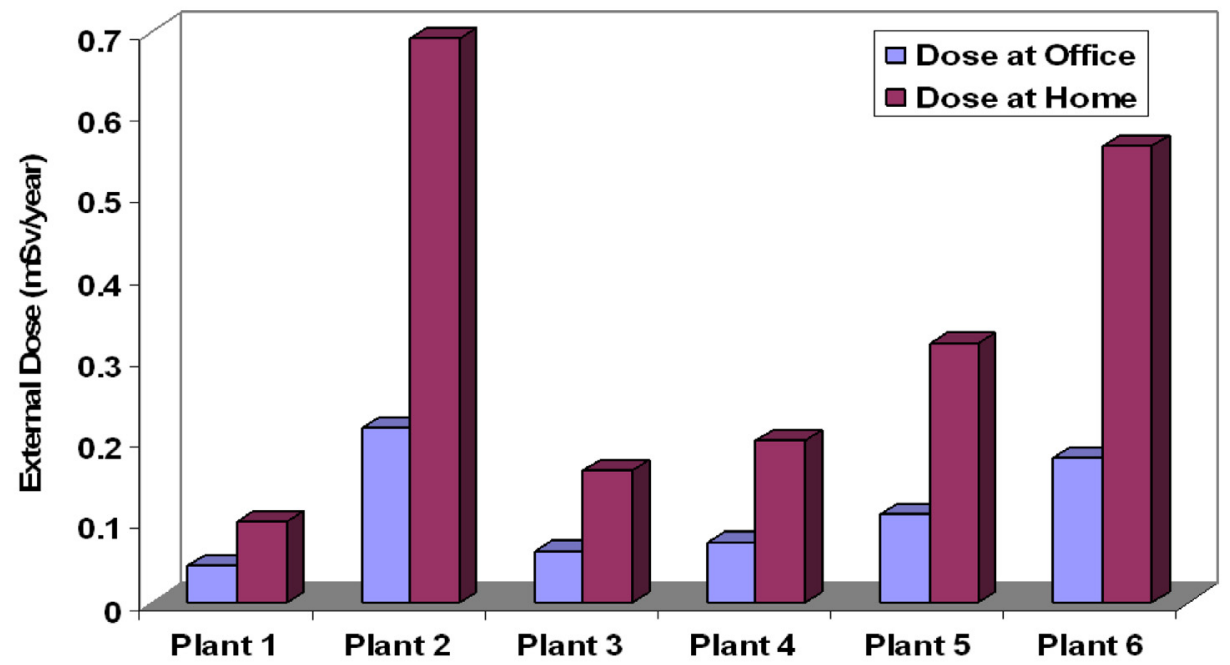

Figure 2. Yearly external dose to the occupants due to the use of fly ash as a construction material.

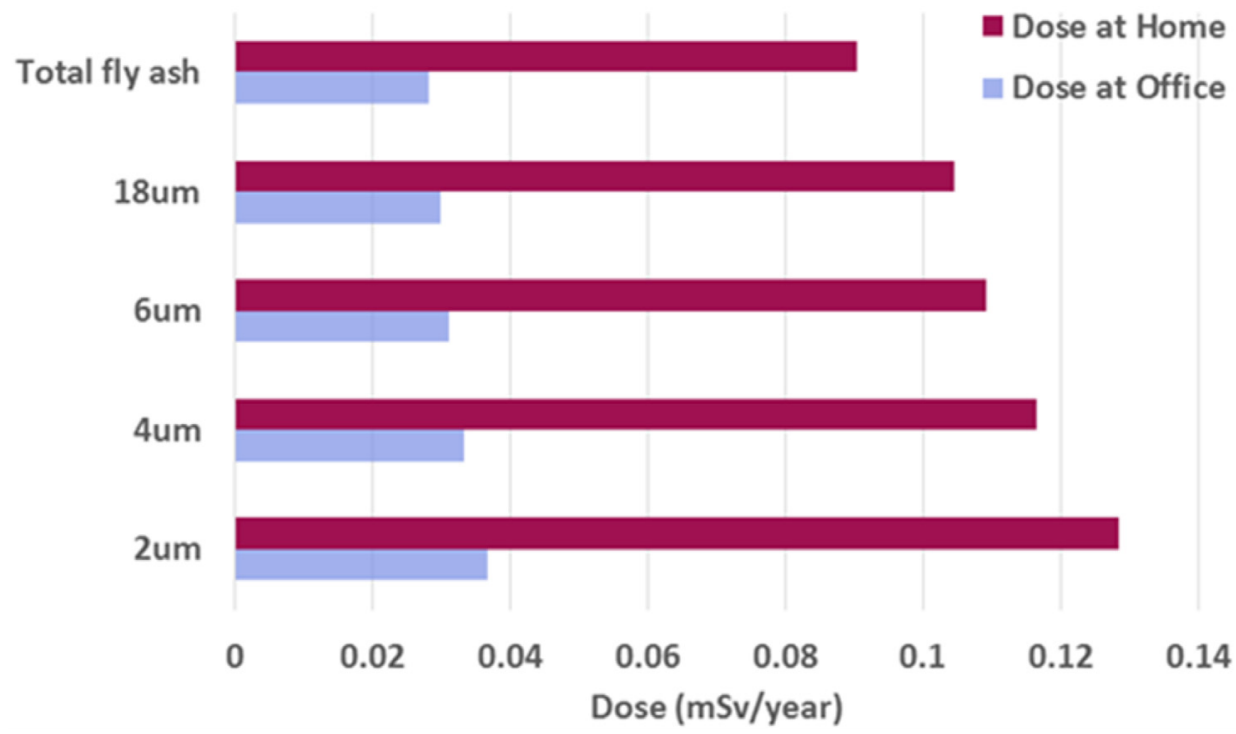

Figure 3. Dependence of the dose on the particle size of the fly ash. 
value of $1 \mathrm{mSv}$ year ${ }^{-1}$. The study on the effect of the ash percentage on the dose showed that the dose increases with an increasing percentage of ash in the concrete. Also, it was observed that a fine fraction of the fly ash particles contributes more toward the total dose than a coarse fraction. The doses determined for the hypothetical room in this study, though small, are important to monitor because of the stochastic health effects associated with radioactivity.

\section{References}

ACI (2009) Manual of concrete practice. Detroit: American Concrete Institute, 2009. Code section ACI 211, 1-91.

Anjos R.M., Umisedo N., da Silva A.A.R., Estellita L., Rizzotto M., Yoshimura E.M., Velasco H., Santos A.M.A. (2010) Occupational exposure to radon and natural gamma radiation in the La Carolina, a former gold mine in San Luis Province, Argentina, J. Environ. Radioact. 10, 153-158.

Bhangare R.C., Ajmal P.Y., Sahu S.K., Pandit G.G., Puranik V.D. (2011) Distribution of trace elements in coal and combustion residues from five thermal power plants in India, Int. J. Coal Geol. 86, 349-356.

Bhangare R.C., Tiwari M., Ajmal P.Y., Sahu S.K., Pandit G.G. (2014) Distribution of natural radioactivity in coal and combustion residues of thermal power plants, J. Radioanal. Nucl. Chem. 300, 17-22.

Da Silva A.A.R., Valladares D.L., Anjos R.M., Velasco H., Rizzotto M., Yoshimura E.M. (2011) Assessment the health hazard from ${ }^{222} \mathrm{Rn}$ in old metalliferous mines in San Luis, Argentina, Wat. Air Soil Poll. 218, 371-386.

de Jong P., van Dijk J.W.E. (2008) Calculation of the indoor gamma dose rate distribution due to building materials in the Netherlands, Radiat. Prot. Dosim. 132 (4), 381-389.

Hassan N.M., Ishikawa T., Hosoda M., Sorimachi A., Tokonami S., Fukushi M., Sahoo S.K. (2010) Assessment of the natural radioactivity using two techniques for the measurement of radionuclide concentration in building materials used in Japan, $J$. Radioanal. Nucl. Chem. 283, 15-21.

Koblinger L. (1984) Mathematical models of external gamma radiation and congruence of measurements, Radiat. Prot. Dosim. 7, 227-234.

Kovler K. (2012) Does the utilization of coal fly ash in concrete construction present a radiation hazard? Construct. Build Mater. 29, 158-166.

Krieger R. (1981) Radioactivity of construction materials. Betonwerk Fertigteil. Techn. 47, 468-473.

Máduar M.F., Hiromoto G. (2004) Evaluation of indoor gamma radiation dose in dwellings, Radiat. Prot. Dosim. 111 (2), 221-228.
Markkanen M. (1995) Radiation Dose Assessments for Materials with Elevated Natural Radioactivity, Report STUK-B-STO 32. Radiation and Nuclear Safety Authority-STUK.

Murray D.M., Burmaster D.E. (1995) Residential air exchange rates in the United States: empirical and estimated parametric distributions by Season and climatic region, Risk Anal. 15, 459-465.

Nazaroff W.M., Nero A.V. (1988) Radon and its decay products in indoor air. Wiley, New York.

Righi S., Bruzzi L. (2006) Natural radioactivity and radon exhalation in building materials used in Italian dwellings, J. Environ. Radioact. 88, 158-170.

Rizzo S., Brai M., Basile S., Bellia S., Hauser S. (2001) Gamma activity and geochemical features of building materials: estimation of gamma dose rate and indoor radon levels in Sicily, Appl. Radiat. Isotopes 55, 259-265.

Sahu S.K., Tiwari M., Bhangare R.C., Pandit G.G. (2014) Enrichment and particle size dependence of polonium and other naturally occurring radionuclides in coal ash, J. Environ. Radioact. 138, 421426.

Sakoda A., Hanamoto K., Yuu Kataoka T., Kawabe A., Yamaoka K. (2010) First model of the effect of grain size on radon emanation, Appl. Radiat. Isotopes 68, 1169-1172.

Siotis I., Wrixon A.D. (1984) Radiological consequences of the use of fly ash in building materials in Greece, Radiat. Prot. Dosim. 7 (1-4), 101-105.

Steinhäusler F. (1996) Environmental ${ }^{220} \mathrm{Rn}$ : a review, Environ. Int. 22, S1111-S1123.

Stranden E. (1979) Radioactivity of building materials and the gamma radiation in dwellings, Phys. Med. Biol. 24, 921-930.

Taylor-Lange S.C., Juenger M.C.G., Jeffrey A.S. (2014) Radon emanation fractions from concretes containing fly ash and metakaolin, Sci. Total Environ. 466-467, 1060-1065.

UNSCEAR (1982) Sources and Effects of Ionizing Radiation. United Nations Scientific Committee on the Effects of Atomic Radiation, United Nations, New York.

UNSCEAR (1988) Sources and Effects of Ionizing Radiation. United Nations Scientific Committee on the Effects of Atomic Radiation, United Nations, New York.

UNSCEAR (1993) Sources and Effects of Ionizing Radiation. United Nations Scientific Committee on the Effects of Atomic Radiation, United Nations, New York.

UNSCEAR (2000) Sources and Effects of Ionizing Radiation. United Nations Scientific Committee on the Effects of Atomic Radiation, United Nations, New York.

Veiga R., Sanches N., Anjos R.M., Macario K., Bastos J., Iguatemy M., Aguiar J.G., Santos A.M.A., Mosquera B., Carvalho C., Baptista F.M., Umisedo N.K. (2006) Measurement of natural radioactivity in Brazilian beach sands, Radiat. Meas. 41, 189-196.

WHO (2009) WHO Handbook on Indoor Radon: A Public Health Perspective. World Health Organization. WHO Press, Geneva, Switzerland.

Cite this article as: S.K. Sahu, R.C. Bhangare, P.Y. Ajmal, G.G. Pandit. Evaluation of the radiation dose due to the use of fly ash from thermal power plants as a building material. Radioprotection 51(2), 135-140 (2016). 